\title{
Reclassification of Pseudomonas aurantiaca as a synonym of Pseudomonas chlororaphis and proposal of three subspecies, $P$. chlororaphis subsp. chlororaphis subsp. nov., $P$. chlororaphis subsp. aureofaciens subsp. nov., comb. nov. and $P$. chlororaphis subsp. aurantiaca subsp. nov., comb. nov.
}

Correspondence

Encarna Velázquez evp@gugu.usal.es

\author{
Alvaro Peix, ${ }^{1}$ Angel Valverde, ${ }^{1} \dagger$ Raúl Rivas, ${ }^{2} \ddagger$ José M. Igual, ${ }^{2}$ \\ Martha-Helena Ramírez-Bahena, ${ }^{2}$ Pedro F. Mateos, ${ }^{2}$ \\ Ignacio Santa-Regina, ${ }^{1}$ Claudino Rodríguez-Barrueco, ${ }^{1}$ \\ Eustoquio Martínez-Molina ${ }^{2}$ and Encarna Velázquez ${ }^{2}$ \\ ${ }^{1}$ IRNASA-CSIC, Apdo 257, 37071 Salamanca, Spain \\ ${ }^{2}$ Departamento de Microbiología y Genetica, Universidad de Salamanca, Spain
}

Pseudomonas chlororaphis, Pseudomonas aureofaciens and Pseudomonas aurantiaca were considered as separate species until 1989, when $P$. aureofaciens was proposed as a later heterotypic synonym of $P$. chlororaphis with $P$. aurantiaca remaining as a separate species. Nevertheless, analysis of the almost complete $16 \mathrm{~S}$ rRNA gene sequences revealed that the type strain of $P$. aurantiaca, NCIMB $10068^{\top}$, shows gene sequence similarities close to $99.5 \%$ with respect to $P$. chlororaphis DSM $50083^{\top}$ and $P$. aureofaciens DSM $6698^{\top}$. DNA-DNA hybridization experiments among strains of $P$. aurantiaca, $P$. chlororaphis and $P$. aureofaciens showed values higher than $70 \%$, confirming that they represent members of the same species. The results of fatty acid analysis and phenotypic traits showed that these strains are closely related, although there are some differences among the strains belonging to $P$. aurantiaca, those from $P$. chlororaphis and those from $P$. aureofaciens. All these results confirm the previous reclassification of $P$. aureofaciens into $P$. chlororaphis and support the reclassification of $P$. aurantiaca as a synonym of $P$. chlororaphis. Phenotypic and molecular data permit the description of three novel subspecies within this last species, for which the following names are proposed: $P$. chlororaphis subsp.

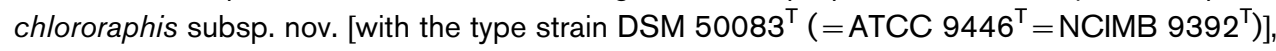
P. chlororaphis subsp. aureofaciens subsp. nov., comb. nov. [with the type strain DSM $6698^{\top}$ $\left(=\right.$ ATCC $13985^{\top}=$ NCIMB $\left.9030^{\top}\right)$ ] and $P$. chlororaphis subsp. aurantiaca subsp. nov., comb. nov. [with the type strain NCIMB $10068^{\top}\left(=\right.$ ATCC $33663^{\top}=$ CIP $\left.106718^{\top}\right)$ ].
Pseudomonas chlororaphis, Pseudomonas aureofaciens and Pseudomonas aurantiaca were included in the Approved Lists of bacterial names (Skerman et al., 1980) and considered as separate species in the first edition of
Bergey's Manual of Systematic Bacteriology by Palleroni, who included the first two species in rRNA group I and $P$. aurantiaca in group V (Palleroni, 1984). Later, the species $P$. aureofaciens was proposed as a later heterotypic synonym of

tPresent address: Department of Plant Pathology and Microbiology, Faculty of Agricultural, Food and Environmental Quality Sciences, The Hebrew University of Jerusalem, Rehovot 76100, Israel.

¥Present address: Laboratorium voor Microbiologie, Vakgroep Biochemie, Fysiologie en Microbiologie, Universiteit Gent KL, Ledeganckstraat 35, B9000 Gent, Belgium.

The GenBank/EMBL/DDBJ accession numbers for the $16 \mathrm{~S}$ rRNA gene sequences of $P$. aurantiaca NCIMB $10068^{\top}$ and $P$. aureofaciens DSM $6698^{\top}$ are D0682655 and AY509898, respectively.

Tables detailing the results of DNA-DNA hybridization studies and fatty acid analyses are available with the online version of this paper. 
P. chlororaphis on the basis of DNA relatedness and phenotypic traits (Johnson \& Palleroni, 1989). Recently, in the second edition of the Bergey's Manual of Systematic Bacteriology, Palleroni (2005) proposed that $P$. aureofaciens and $P$. chlororaphis may be considered as two subspecies of the same species and that $P$. aurantiaca remains a separate species. In 1985, a taxonomic study of $P$. aurantiaca was published outside of the International Journal of Systematic Bacteriology by Kiprianova et al. (1985) who proposed the selection of a neotype strain for this species. Their conclusion was based on phenotypic data from the type strain received from the VKM collection, which showed different characteristics from those recorded in the literature for $P$. aurantiaca. An analysis of the type strains of $P$. aurantiaca available from other culture collections was not performed, or at least was not recorded in the cited paper, and therefore the decision to designate a neotype strain was not strongly supported and was never officially approved.

The type strain of $P$. aurantiaca available at the NCIMB and used in our study fulfils the characteristics described for $P$. aurantiaca as recorded in the different editions of Bergey's Manual of Systematic Bacteriology. The 16S rRNA gene sequence of $P$. aurantiaca NCIMB $10068^{\mathrm{T}}$ obtained in this study is $100 \%$ similar to that of strain ATCC $33663^{\mathrm{T}}$ available at GenBank (Anzai et al., 2000). This result is congruent with the fact that the ATCC received the strain from the NCIMB, from where it was also sent to the LMG and the CIP collections. Therefore, the original type strain of $P$. aurantiaca is currently available in several collections and the selection of a neotype strain is thus not necessary.

The 16S rRNA gene sequence of the type strain of $P$. aurantiaca showed a similarity greater than $99 \%$ with respect to those of $P$. chlororaphis DSM $50083^{\mathrm{T}}$ and $P$. aureofaciens DSM $6698^{\mathrm{T}}$ as obtained in this study. Moreover, a recent study of atpD, recA and carA gene sequences from Pseudomonas species showed that the type strain of $P$. aurantiaca belongs to the same phylogenetic group as $P$. chlororaphis and $P$. aureofaciens, with gene sequence similarities greater than $96 \%$ (Hilario et al., 2004), suggesting that they belong to the same species. Although they show several phenotypic differences that have been pointed out by several authors (Palleroni, 1984, 2005; Kiprianova et al., 1985; Johnson \& Palleroni, 1989), the strains belonging to $P$. aurantiaca, $P$. chlororaphis and $P$. aureofaciens are phenotypically close. In this work, we therefore performed a polyphasic study in order to clarify the taxonomic status of $P$. aurantiaca in comparison with strains of $P$. chlororaphis and $P$. aureofaciens. From the results obtained, we conclude that $P$. aurantiaca is a subspecies of Pseudomonas chlororaphis and propose the name Pseudomonas chlororaphis subsp. aurantiaca subsp. nov., comb. nov. The names $P$. chlororaphis subsp. chlororaphis subsp. nov. and $P$. chlororaphis subsp. aureofaciens subsp. nov., comb. nov. are also proposed. The names of these novel subspecies were originally proposed by Palleroni (2005) but have not been validly published.
The 16S rRNA gene sequences of $P$. aurantiaca ATCC $33663^{\mathrm{T}}$ and P. aureofaciens ATCC $12353^{\mathrm{T}}$ were obtained by Anzai et al. (2000) and deposited in GenBank with accession numbers AB021412 and D84008, respectively. However, both sequences contain several undetermined nucleotides. Other sequences of the same strains held in public databases are not complete and so in this study, the 16S rRNA gene sequences of $P$. aurantiaca NCIMB $10068^{\mathrm{T}}$ (GenBank accession no. DQ682655) and P. aureofaciens DSM $6698^{\mathrm{T}}$ (AY509898) were determined according to a previously described method (Rivas et al., 2003). The sequences were compared with those deposited in GenBank using the BLASTN programme (Altschul et al., 1990) and were aligned using CLUSTAL_X software (Thompson et al., 1997). Distances were calculated according to Kimura's method (Kimura, 1980). Phylogenetic trees were inferred using the neighbour-joining method (Saitou \& Nei, 1987). Bootstrap analysis was based on 1000 resamplings. The MEGA2 package (Kumar et al., 2001) was used for all analyses.

Fig. 1 shows a phylogenetic tree that includes representative species of the genus Pseudomonas sensu stricto. The $16 \mathrm{~S}$ rRNA gene sequence of strain DSM $50083^{\mathrm{T}}$ showed 99.5 and $99.4 \%$ similarity to those of strains DSM $6698^{\mathrm{T}}$ and NCIMB $10068^{\mathrm{T}}$, respectively. Strains DSM $6698^{\mathrm{T}}$ and NCIMB $10068^{\mathrm{T}}$ showed $99.7 \%$ gene sequence similarity to eachother. The three strains formed a separate group from other species of the genus Pseudomonas sensu stricto.

DNA-DNA hybridization experiments were carried out by using the method of Ezaki et al. (1989), following the recommendations of Willems et al. (2001). Besides the type strains, several strains of $P$. chlororaphis, $P$. aurantiaca and $P$. aureofaciens were also included (see Supplementary Table S1 in IJSEM Online). The DNA-DNA hybridization results showed that, in agreement with the 16S rRNA gene sequence similarities, the highest hybridization values were found between $P$. aureofaciens DSM $6698^{\mathrm{T}}$ and $P$. aurantiaca NCIMB $10068^{\mathrm{T}}$ with a mean similarity of $81 \%$. P. chlororaphis DSM $50083^{\mathrm{T}}$ displayed 75 and $73 \%$ DNA-DNA hybridization with respect to $P$. aurantiaca NCIMB $10068^{\mathrm{T}}$ and $P$. aureofaciens DSM $6698^{\mathrm{T}}$, respectively. Values ranging between 60 and $87 \%$ were obtained for other strains of the three species analysed (see Supplementary Table S1). Although some of these values are slightly lower than the threshold value of $70 \%$ DNA-DNA similarity recommended for the delineation of species (Wayne et al., 1987), the type strains of these species showed values higher than $75 \%$.

Fatty acid analyses were performed with cultures grown for $24 \mathrm{~h}$ in TSA medium (Merck) at $28^{\circ} \mathrm{C}$ as already described (Peix et al., 2003). The main non-polar fatty acids detected were $\mathrm{C}_{16: 0}$ and those summed in summed feature 3 $\left(\mathrm{C}_{16: 1} \omega 7 c\right.$ and $\mathrm{C}_{15: 0}$ iso 2-OH).The amounts of fatty acid $\mathrm{C}_{16: 0}$ and summed feature 3 were, respectively, $33.4 \%$ and $34.8 \%$ in strain DSM $50083^{\mathrm{T}}, 26.3 \%$ and $34.8 \%$ in strain DSM $6698^{\mathrm{T}}$ and $30.3 \%$ and $25.3 \%$ in strain NCIMB $10068^{\mathrm{T}}$. The full fatty acid contents of the strains are shown in 


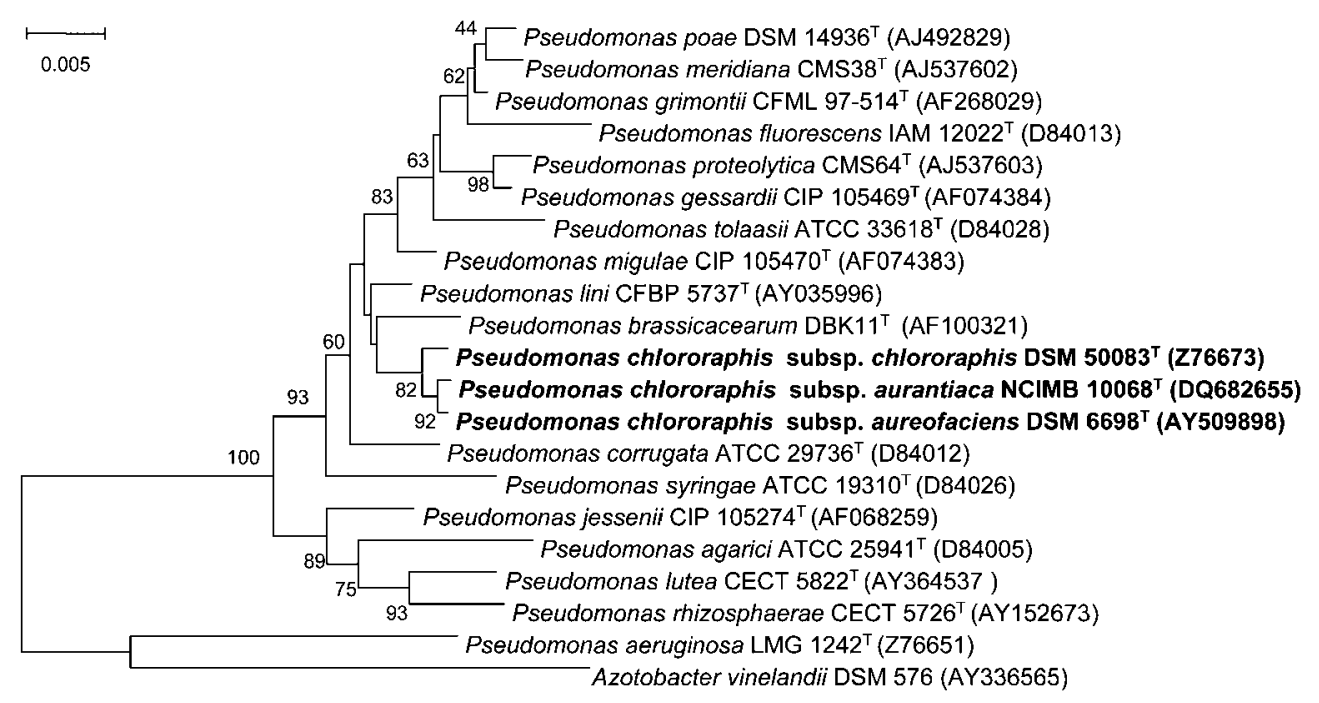

Fig. 1. Neighbour-joining tree based on nearly complete $16 \mathrm{~S}$ rRNA gene sequences of the subspecies of Pseudomonas chlororaphis and other related organisms of the genus Pseudomonas. The significance of each branch is indicated by a bootstrap value calculated for 1000 subsets. Bar, 5 nucleotide substitutions per 1000 nucleotides.

Supplementary Table S2 in IJSEM Online. Small differences in the amounts of some other fatty acids were found between the three strains. For example, strains DSM $50083^{\mathrm{T}}$ and DSM $6698^{\mathrm{T}}$ differ in the amount of $\mathrm{C}_{12: 0}, \mathrm{C}_{16: 0}, \mathrm{C}_{10: 0} 3-\mathrm{OH}$ and $\mathrm{C}_{12: 1} 3-\mathrm{OH}$; strains DSM $50083^{\mathrm{T}}$ and NCIMB $10068^{\mathrm{T}}$ differ in $\mathrm{C}_{10: 0} 3-\mathrm{OH}, \mathrm{C}_{12: 1} 3-\mathrm{OH}, \mathrm{C}_{12: 0} 3-\mathrm{OH}, \mathrm{C}_{17: 0}$ cyclo and summed feature 3 , and strains DSM $6698^{\mathrm{T}}$ and NCIMB $10068^{\mathrm{T}}$ differ in $\mathrm{C}_{10: 0} 3-\mathrm{OH}, \mathrm{C}_{12: 0} 3-\mathrm{OH}, \mathrm{C}_{17: 0}$ cyclo and summed feature 3 .

The same strains that were included in the DNA-DNA hybridization experiments were also studied phenotypically by using the API $20 \mathrm{NE}$ and API $50 \mathrm{CH}$ systems as recommended by the manufacturer. The results of the phenotypic characterization concurred with those reported by Johnson \& Palleroni (1989), who proposed the reclassification of $P$. aureofaciens as $P$. chlororaphis, and with those reported by Doudoroff \& Palleroni (1974) and Palleroni (1984, 2005).
According to these results, strains of $P$. aureofaciens use $\mathrm{L}$-arabinose as a carbon source in both API 20NE and API $50 \mathrm{CH}$ tests while those strains belonging to $P$. chlororaphis do not. Nitrate reduction was positive for $P$. chlororaphis strains, negative in strains of $P$. aurantiaca and variable for strains of $P$. aureofaciens. P. aurantiaca strains differed from $P$. aureofaciens in the use of 5-ketogluconate and from $P$. chlororaphis strains in the use of both 5-ketogluconate and Larabinose (Table 1).

The results of fatty acid analysis, phenotypic characterization, 16S rRNA gene sequencing, DNA-DNA relatedness, as well as the results obtained by Hilario et al. (2004) on the phylogenetic analysis of several housekeeping genes, support the reclassification of $P$. aurantiaca as a later heterotypic synonym of $P$. chlororaphis. The results also revealed that strains of $P$. aurantiaca, $P$. aureofaciens and $P$. chlororaphis form three clearly distinguishable groups within $P$.

Table 1. Phenotypic differences among the subspecies of $P$. chlororaphis

Data are from Palleroni (1984, 2005), Johnson \& Palleroni (1989) and this study. +, Positive; -, negative; $\mathrm{V}$, variable.

\begin{tabular}{|lccc|}
\hline & $\begin{array}{c}\text { P. chlororaphis } \\
\text { subsp. chlororaphis }\end{array}$ & $\begin{array}{c}\text { P. chlororaphis } \\
\text { subsp. aureofaciens }\end{array}$ & $\begin{array}{c}\text { P. chlororaphis } \\
\text { subsp. aurantiaca }\end{array}$ \\
\hline Non-fluorescent pigments: & & & + \\
$\quad$ Green (chlororaphin) & + & - & + \\
Orange (phenazine-1-carboxylate) & - & + & - \\
Denitrification & + & $\mathrm{V}$ & + \\
Assimilation as carbon source: & - & + & - \\
L-Arabinose & + & + & + \\
5-Ketogluconate & + & & + \\
\hline
\end{tabular}


chlororaphis that merit the status of subspecies. Therefore, we propose the establishment of three novel subspecies within P. chlororaphis; P. chlororaphis subsp. chlororaphis subsp. nov., $P$. chlororaphis subsp. aureofaciens subsp. nov., comb. nov. and $P$. chlororaphis subsp. aurantiaca subsp. nov., comb. nov.

\section{Emended description of Pseudomonas chlororaphis (ex Guignard and Sauvageau 1894) Bergey et al. $1930^{\mathrm{AL}}$}

Characteristics in addition to those reported in the original description recorded in Bergey's Manual of Determinative Bacteriology (Doudoroff \& Palleroni, 1974) are as follows. The main non-polar fatty acids detected are $\mathrm{C}_{16: 0}$ and summed feature 3 , comprising around $30 \%$ of total fatty acids, followed by $\mathrm{C}_{18: 1} \omega 7 c$, with amounts of approximately $10 \%$. A more detailed breakdown of fatty acid content is presented in Supplementary Table S2. Negative result in tests for urease, $\beta$-galactosidase, indole production and aesculin hydrolysis. Nitrate reduction is variable. $\mathrm{N}$-acetylglucosamine, trehalose, raffinose and D-arabitol are used as carbon sources. Assimilation of L-arabinose, phenylacetate and 5-ketogluconate is variable. The use of L-xylose, sorbose, amygdalin, arbutin, salicin, melibiose, melezitose, starch, glycogen, gentiobiose, turanose, lyxose, tagatose, Lfucose, L-arabitol, xylitol, dulcitol, methyl $\alpha$-D-glucoside, methyl $\alpha$-D-mannoside and methyl $\beta$-D-xyloside is negative. The DNA G + C content ranges from 63.5 to $63.6 \mathrm{~mol} \%$.

\section{Description of Pseudomonas chlororaphis subsp. chlororaphis subsp. nov.}

Pseudomonas chlororaphis subsp. chlororaphis (chlo.ro.ra' phis. Gr. adj. chlorus green; Gr. n. raphis a needle; N.L. fem. n. chlororaphis a green needle).

Displays characteristics typical for the species $P$. chlororaphis as described above. Chlororaphin, a green insoluble phenazine pigment, is produced. Nitrate reduction is positive. Utilization of L-arabinose is negative. Utilization of 5ketogluconate is positive. Phylogeny based on 16S rRNA, atpD, recA and car $A$ gene sequences separates this subspecies from the other subspecies of $P$. chlororaphis.

The type strain is DSM $50083^{\mathrm{T}}\left(=\mathrm{ATCC} 9446^{\mathrm{T}}=\mathrm{NCIMB}\right.$ $\left.9392^{\mathrm{T}}\right)$.

\section{Description of Pseudomonas chlororaphis subsp. aureofaciens subsp. nov., comb. nov.}

Pseudomonas chlororaphis subsp. aureofaciens (au.re.o.fa' ci.ens. L. adj. aureus golden; L. part. adj. faciens producing; N.L. part. adj. aureofaciens golden-producing, referring to the pigment produced).

Displays characteristics typical for the species $P$. chlororaphis as described above. Produces a diffusible yellow-orange phenazine pigment. Nitrate reduction is variable. Utilization of L-arabinose is positive. Utilization of 5-ketogluconate is positive or weakly positive. Phylogeny based on $16 \mathrm{~S}$ rRNA, atpD, recA and carA gene sequences separates this subspecies from the other subspecies of $P$. chlororaphis.

The type strain is DSM $6698^{\mathrm{T}}\left(=\mathrm{ATCC} 13985^{\mathrm{T}}=\mathrm{NCIMB}\right.$ $\left.9030^{\mathrm{T}}\right)$.

\section{Description of Pseudomonas chlororaphis subsp. aurantiaca subsp. nov., comb. nov.}

Pseudomonas chlororaphis subsp. aurantiaca (au.ran.ti.a'ca. N.L. fem. adj. aurantiaca orange-coloured).

Displays characteristics typical for the species $P$. chlororaphis as described above. Green and orange pigments are produced. Nitrate reduction is negative. Utilization of L-arabinose is positive. Utilization of 5-ketogluconate is negative. Phylogeny based on $16 \mathrm{~S}$ rRNA, atpD, recA and carA gene sequences separates this subspecies from the other subspecies of $P$. chlororaphis.

The type strain is NCIMB $10068^{\mathrm{T}}\left(=\operatorname{ATCC} 33663^{\mathrm{T}}=\mathrm{CIP}\right.$ $\left.106718^{\mathrm{T}}\right)$.

\section{References}

Altschul, S. F., Gish, W., Miller, W., Myers, E. W. \& Lipman, D. J. (1990). Basic local alignment search tool. J Mol Biol 215, 403-410.

Anzai, Y., Kim, H., Park, J. Y., Wakabayashi, H. \& Oyaizu, H. (2000). Phylogenetic affiliation of the pseudomonads based on 16S rRNA sequence. Int J Syst Evol Microbiol 50, 1563-1589.

Doudoroff, M. \& Palleroni, N. (1974). Gram negative aerobic rods and cocci. Genus I. Pseudomonas Migula 1894, 23. In Bergey's Manual of Determinative Bacteriology, 8th edition, edited by R. E. Buchanan \& N. E. Gibbons, pp. 217-249. Baltimore: Williams \& Wilkins.

Ezaki, T., Hashimoto, Y. \& Yabuuchi, E. (1989). Fluorometric deoxyribonucleic acid-deoxyribonucleic acid hybridization in microdilution wells as an alternative to membrane filter hybridization in which radioisotopes are used to determine genetic relatedness among bacterial strains. Int J Syst Bacteriol 39, 224-229.

Hilario, E., Buckley, T. R. \& Young, J. M. (2004). Improved resolution on the phylogenetic relationships among Pseudomonas by the combined analysis of $a t p D, \operatorname{car} A, \operatorname{rec} A$ and $16 \mathrm{~S}$ rDNA. Antonie van Leeuwenhoek 86, 51-64.

Johnson, J. L. \& Palleroni, N. (1989). Deoxyribonucleic acid similarities among Pseudomonas species. Int J Syst Bacteriol 39, 230-235.

Kimura, M. (1980). A simple method for estimating evolutionary rates of base substitutions through comparative studies of nucleotide sequences. J Mol Evol 16, 111-120.

Kiprianova, E. A., Levanova, G. F., Novova, E. V., Smirnov, V. V., Garagulya, A. D. \& Boiko, O. I. (1985). Taxonomic study of Pseudomonas aurantiaca Nakhimovskaya, 1948 and the proposal of a neotype strain of this species. Mikrobiologiia 54, 434-440 (in Russian).

Kumar, S., Tamura, K., Jakobsen, I. B. \& Nei, M. (2001). Molecular Evolutionary Genetics Analysis software. Arizona State University. Tempe, AZ, USA.

Palleroni, N. J. (1984). Family I. Pseudomonadaceae Winslow, Broadhurst, Buchanan, Krumwiede, Rogers and Smith 1917, 555. In Bergey's Manual of Systematic Bacteriology, 1st edn, pp. 141-218. Edited by P. H. A. Sneath, N. S. Mair, M. E. Sharpe \& J. G. Holt. Baltimore: Williams \& Wilkins. 
Palleroni, N. J. (2005). Genus I. Pseudomonas. In Bergey's Manual of Systematic Bacteriology, 2nd edn, vol. 2, pp. 323-379. Edited by D. J. Brenner, N. R. Krieg, J. T. Staley \& G. M. Garrity. East Lansing: Springer.

Peix, A., Rivas, R., Mateos, P. F., Martínez-Molina, E., RodríguezBarrueco, C. \& Velázquez, E. (2003). Pseudomonas rhizosphaerae sp. nov., a novel species that actively solubilizes phosphate in vitro. Int J Syst Evol Microbiol 53, 2067-2072.

Rivas, R., Willems, A., Subba-Rao, N. S., Mateos, P. F., Dazzo, F. B., Martínez-Molina, E., Gillis, M. \& Velázquez, E. (2003). Description of Devosia neptuniae sp. nov. that nodulates and fixes nitrogen in symbiosis with Neptunia natans, an aquatic legume from India. Syst Appl Microbiol 26, 47-53.

Saitou, N. \& Nei, M. (1987). A neighbour-joining method: a new method for reconstructing phylogenetic trees. Mol Biol Evol 44, 406-425.
Skerman, V. B. D., McGowan, V. \& Sneath, P. H. A. (editors) (1980). Approved lists of bacterial names. Int J Syst Bacteriol 30, 225-420.

Thompson, J. D., Gibson, T. J., Plewniak, F., Jeanmougin, F. \& Higgins, D. G. (1997). The CLUSTAL_X windows interface: flexible strategies for multiple sequence alignment aided by quality analysis tools. Nucleic Acids Res 25, 4876-4882.

Wayne, L. G., Brenner, D. J., Colwell, R. R., Grimont, P. A. D., Kandler, O., Krichevsky, M. I., Moore, L. H., Moore, W. E. C., Murray, R. G. E. \& other authors (1987). International Committee on Systematic Bacteriology. Report of the ad hoc committee on reconciliation of approaches to bacterial systematics. Int $J$ Syst Bacteriol 37, 463-464.

Willems, A., Doignon-Bourcier, F., Goris, J., Coopman, R., de Lajudie, P., De Vos, P. \& Gillis, M. (2001). DNA-DNA hybridization study of Bradyrhizobium strains. Int J Syst Evol Microbiol 51, 1315-1322. 